\title{
RESISTANCE TO COMPRESSION OF STRUCTURAL CONCRETE WITH STEEL AND POLYPROPYLENE FIBERS
}

\author{
Josué Araujo Novoa, Marlon Farfán Córdova \\ Universidad César Vallejo, Av. Larco 1770-Trujillo - La Libertad
}

\begin{abstract}
The influence of steel and polypropylene fibers on the resistance to compression of concrete is evaluated. NTP 339.034 and ASTM C39 were used to test compressive strength in four groups with a total of 48 specimens distributed in a control group and three experimental groups during 14 and 28 days of curing. The compressive strength test was determined for an average compressive strength of $f^{\prime} \mathrm{cr}=294 \mathrm{~kg} / \mathrm{cm}^{2}(28.8$ $\mathrm{MPa}$ ), according to E 060 reinforced concrete standard. Group G1 presented a dosification of steel and polypropylene fibers of $10 \%$ by $25 \mathrm{~kg} / \mathrm{m}^{3}$ and $600 \mathrm{gr} / \mathrm{m}^{3}$, group G2 $15 \%$ by $25 \mathrm{~kg} / \mathrm{m}^{3}$ and $600 \mathrm{gr} / \mathrm{m}^{3}$, group $\mathrm{G} 320 \%$ by $25 \mathrm{~kg} / \mathrm{m}^{3}$ and $600 \mathrm{gr} / \mathrm{m}^{3}$ and $\mathrm{G} 4$ was not supplied with steel and polypropylene fibers. The specimens were subjected to compression tests at the age of 14 and 28 days, obtaining as a result that the most favorable group is the G3 group with a resistance of $322.98 \mathrm{~kg} / \mathrm{m}^{2}(31.67 \mathrm{MPa})$, exceeding the control group by $8.10 \%$. It is evident that the presence of steel and polypropylene fibers in concrete significantly increase its resistance to compression.
\end{abstract}

Keywords: Concrete, strength/resistance, compression, steel fibers and polypropylene fibers.

Cite this Article: Josué Araujo Novoa and Marlon Farfán Córdova, Resistance to Compression of Structural Concrete with Steel and Polypropylene Fibers, International Journal of Civil Engineering and Technology, 11(03), 2020, pp.64-73

https://iaeme.com/Home/issue/IJCIET?Volume=11\&Issue=3

\section{INTRODUCTION}

Nowadays, one of the most used materials in civil constructions is concrete due to the fact that it presents versatility, workability, and durability and has great resistance that contributes a lot in its physical states in which it is found. Concrete is used for a varied field of application, which is given in buildings, bridges, works of art, etc., and its composition is given by coarse aggregate, fine aggregate, water and a binder (cement), and if it were the case, with an additive. This composition, when it reaches its hardened state, is used for various engineering 
applications, such as foundations, subflooring's, pillars, columns, beams, either ribbed or solid slabs, reservoirs, bridges, etc. [1].

Fibers give better performance to the concrete before and after cracking, which has generated greater interest in recent years. For four decades, various fiber types have been used in concrete in a satisfactory way, because they improve all its physical and mechanical characteristics, and above all they give the concrete more durability. The most important advantages of incorporating steel filaments into concrete are: it provides bending strength (absorbs energy after cracking), which increases shear, direct stress and torsional resistance; it increases impact and fatigue resistance properties, enhances plastic flow and shrinkage behavior and increases durability in certain climatic conditions [2]. The current trend to use better materials and construction systems has led to the use of steel fibers to reinforce concrete.

At present, several studies have been carried out that show steel and polypropylene filaments as a different option for the design and construction of structures that require special characteristics. The use of fibers as an additional reinforcement to filler materials dates back several decades, and has been experimented with different types of reinforcements, including nails, cable segments and hooks [3]. Steel fibers are mostly used in pre-fabricated reinforced concrete because they can be used in large areas such as rigid pavement slabs (light, medium and high), concrete slabs to replace steel and foundations, airports, ports, foundations for vibrating equipment, tanks, reservoirs, etc. [4].

In the city of Trujillo, the real estate boom generated in recent years has not occurred in an orderly way, as shown by estimates made by the Urban Development Management of the provincial municipality, in which $60 \%$ of constructions in the district is informal. In the absence of technical assistance in building construction, problems arise due to lack of knowledge, such as deficient housing structure, low construction quality and architectural deficiencies [5]. In this sense, this study determines the adequate proportion of steel and polypropylene fibers to obtain the maximum compressive strength of the concrete and compare it to that of conventional concrete.

\section{MATERIALS AND METHODS}

The research design was pure experimental with post-test only and control group, using dosages of $10 \%, 15 \%$ and $20 \%$ steel fibers (SF) and polypropylene fibers (PF) at 14 and 28 days of curing. The sample was selected according to the Peruvian Technical Standard NTP 339.034 [6] and was made up of 48 specimens, distributed equally according to the days of curing. Four types of mixtures were designed according to the ACI 2010 method [7]: simple concrete (SC), SC plus 10\% of SF and PF (SC10SPF), SC plus 15\% of SF and PF (SC15SPF) and SC plus $20 \%$ of SF and PF (SC20SPF), $25 \mathrm{~kg} / \mathrm{m}^{3}$ for SF and $600 \mathrm{gr} / \mathrm{m} 3$ for PF. For each experimental and control group, 3 trials were conducted which resulted from the average of 2 specimens. Slumps tests were performed for each of the mixtures in the fresh state under NTP 339.035 [8] and ASTM C 143 [9], and in the hardened state the compressive strength was measured according to ASTM C39 [10].

The results of the compression trials were processed using ANOVA (analysis of variance) to determine the differences in resistance among the test groups. The Tukey test was then used for multiple comparisons, useful for identifying pairs of groups which are significantly different from each other, at a significance level of $5 \%$. 


\section{RESULTS AND DISCUSSION}

\subsection{Characterization of materials and design of mixtures:}

The analysis of aggregates is fundamental to carry out the design of mixtures because all the required physical characteristics are obtained. Table 1 shows these characteristics.

Table 1. Physical characteristics of fine and coarse aggregates.

\begin{tabular}{|c|c|c|}
\hline \multirow{2}{*}{ Description } & \multicolumn{2}{|c|}{ Aggregates } \\
\cline { 2 - 3 } & Fine & Coarse \\
\hline $\begin{array}{c}\text { Specific mass weight }\left(\mathrm{gr} / \mathrm{cm}^{3}\right) \\
\text { Loose unit weight }\left(\mathrm{Kg} / \mathrm{m}^{3}\right)\end{array}$ & 2.58 & 2.59 \\
1525.89 & 1482.64 \\
\hline $\begin{array}{c}\text { Dry compacted unit weight - ASTM C 129 [11] } \\
\left(\mathrm{Kg} / \mathrm{m}^{3}\right)\end{array}$ & 1726.48 & 1578.37 \\
\hline Absorption rate - ASTM C 29 [12] (\%) & 1.77 & 2.12 \\
\hline Moisture Content - ASTM D 2216 [13] (\%) & 1.96 & 0.61 \\
\hline Modulus of Fineness - ASTM C 125 [14] & 2.66 & - \\
\hline Maximum nominal size of coarse aggregate (in.) & - & $1 "$ \\
\hline
\end{tabular}

": inches.

Figures 1 and 2 present the granulometry obtained in the tests carried out on the fine and coarse aggregate, respectively.

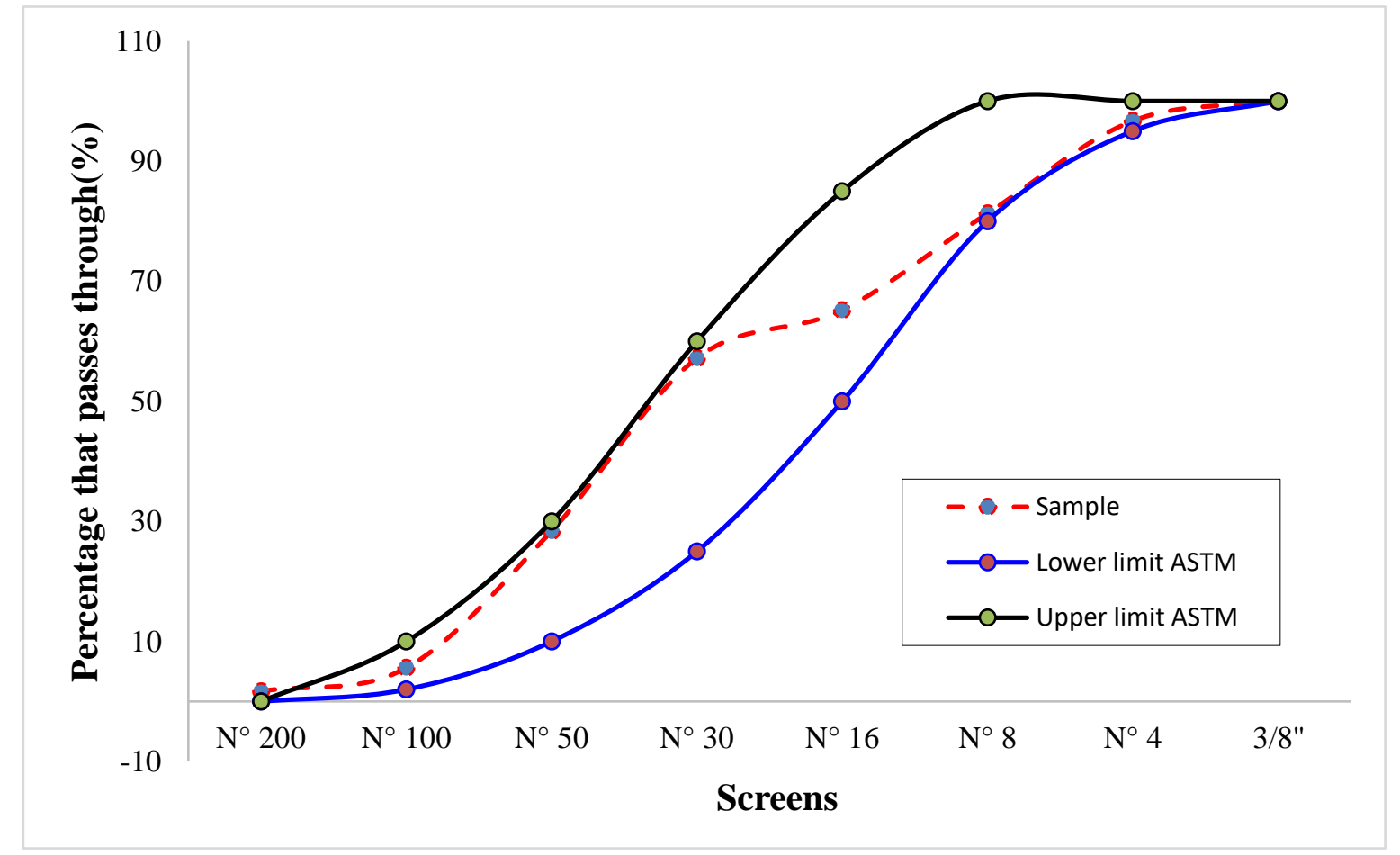

Figure 1. Granulometric curve of fine aggregate - ASTM C33 specification limits [15]. 


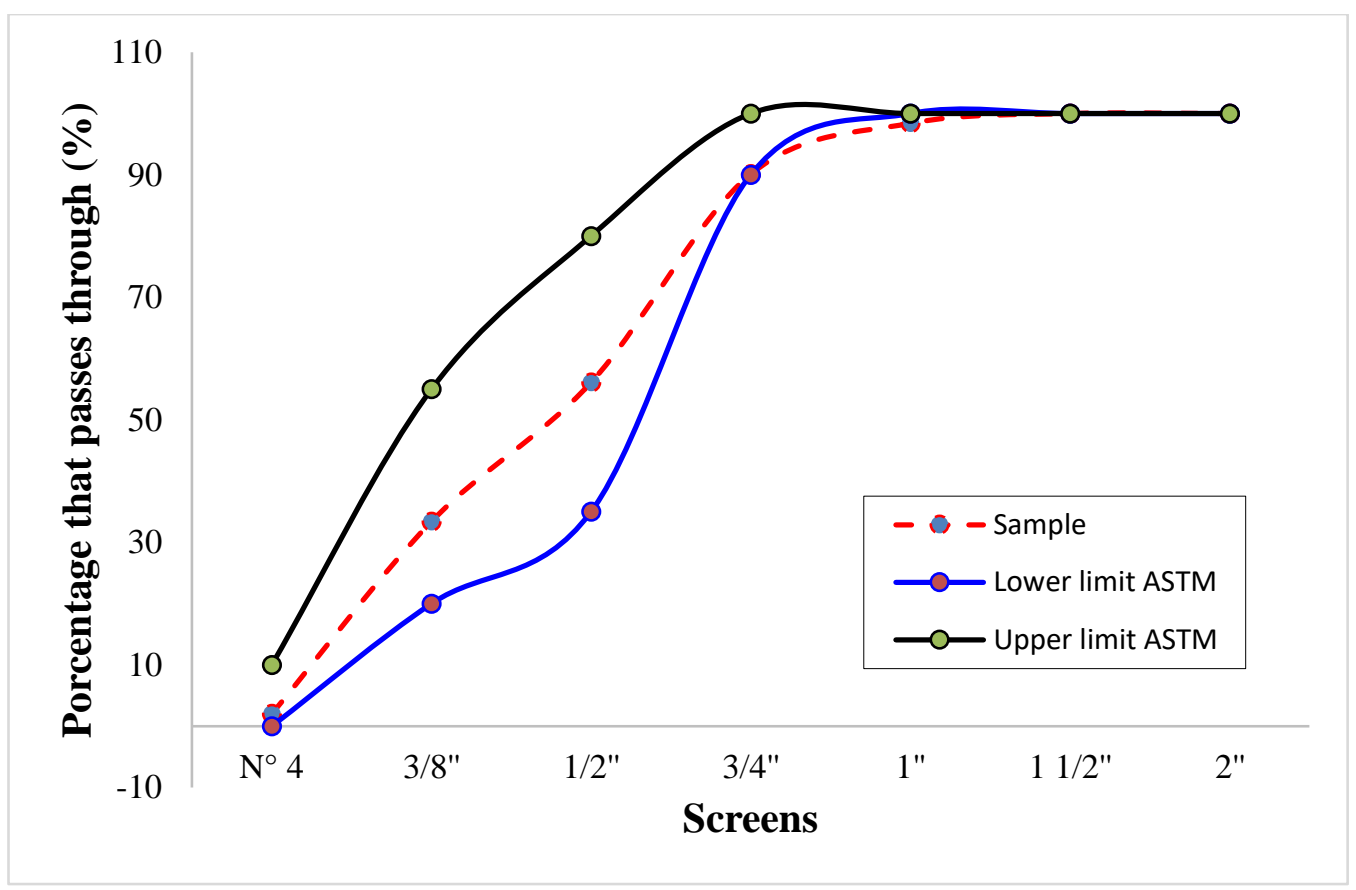

Figure 2. Granulometric curve of coarse aggregate - ASTM C33 specification limits [15].

The design of the concrete mixture was carried out following the ACI COMMITTEE 211 (ACI 2010) procedure [7], as indicated in Table 2.

Table 2. Single concrete mix design for $210 \mathrm{Kg} / \mathrm{cm}^{2}$ with a/c ratio of 0.6

\begin{tabular}{|c|c|c|c|}
\hline \multicolumn{5}{|l|}{} \\
\hline Cement & 1.00 & 345.63 & 14.91 \\
\hline Water & 0.60 & 208.10 & 8.98 \\
\hline Coarse aggregate & 3.14 & 1086.60 & 46.87 \\
\hline Fine aggregate & 1.96 & 678.18 & 29.25 \\
\hline Total for $\mathbf{1 m}^{\mathbf{3}}$ & & 2318.51 & 100.0 \\
\hline
\end{tabular}

\subsection{Testing of fresh and hardened concrete}

The slump test was conducted in accordance with NTP 339.035 [8] and ASTM C 143 [9], which serves to determine the consistency or fluidity of the mixture. The results of this test are shown in Table 3 . In all cases, with the addition of steel and polypropylene fibers, the workability and handling is reduced.

Table 3. Maximum fresh concrete slump.

\begin{tabular}{|c|c|c|}
\hline Group & SLUMP (inches) & \% Variation \\
\hline SC & 3.7 & $0 \%$ \\
\hline SC10SPF & 3.5 & $-5.4 \%$ \\
\hline SC15SPF & 3.3 & $-10.8 \%$ \\
\hline SC20SPF & 3.0 & $-19 \%$ \\
\hline
\end{tabular}


The tests on the samples in the hardened state were carried out on cylindrical specimens with a diameter of $150 \mathrm{~mm}$ and a height of $300 \mathrm{~mm}$, as shown in Table 4 and Figures 3 and 4.

Table 4. Resistance to compression of hardened concrete specimens at various curing ages.

\begin{tabular}{|c|c|c|c|c|}
\hline \multirow{2}{*}{ Mixture } & \multicolumn{4}{|c|}{ Resistance to compression $(\mathrm{Kg} / \mathrm{cm} 2)$} \\
\cline { 2 - 5 } & 14 days & $\%$ scope & 28 days & $\%$ scope \\
\hline SC & 169.90 & 57.79 & 293.90 & 99.96 \\
\hline SC10SPF & 174.10 & 59.22 & 305.96 & 104.07 \\
\hline SC15SPF & 176.47 & 60.02 & 311.62 & 105.99 \\
\hline SC20SPF & 183.15 & 62.30 & 319.61 & 108.71 \\
\hline
\end{tabular}

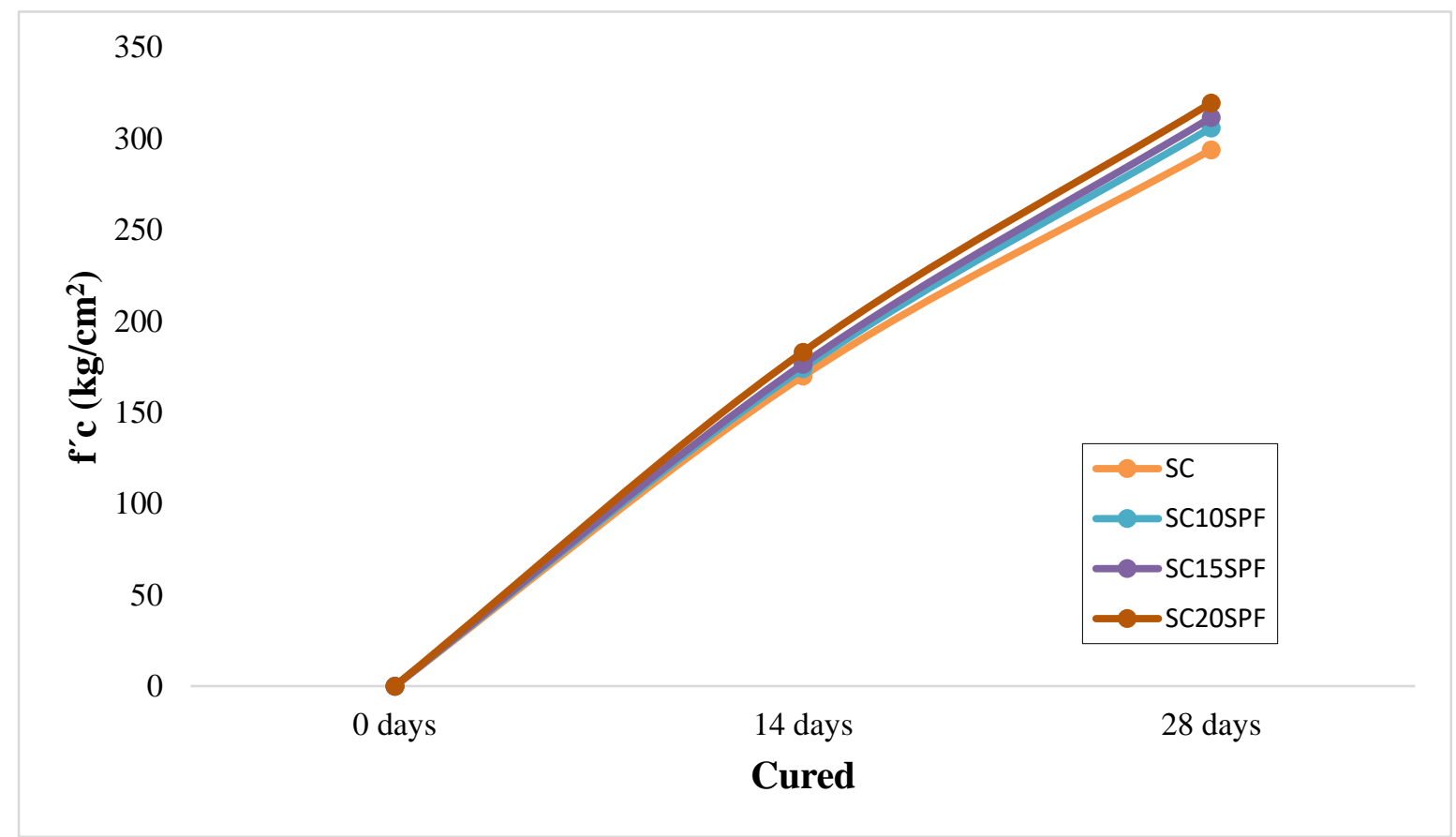

Figure 3. Resistance to compression of the concrete in a hardened state according to curing time. 
Resistance to Compression of Structural Concrete with Steel and Polypropylene Fibers

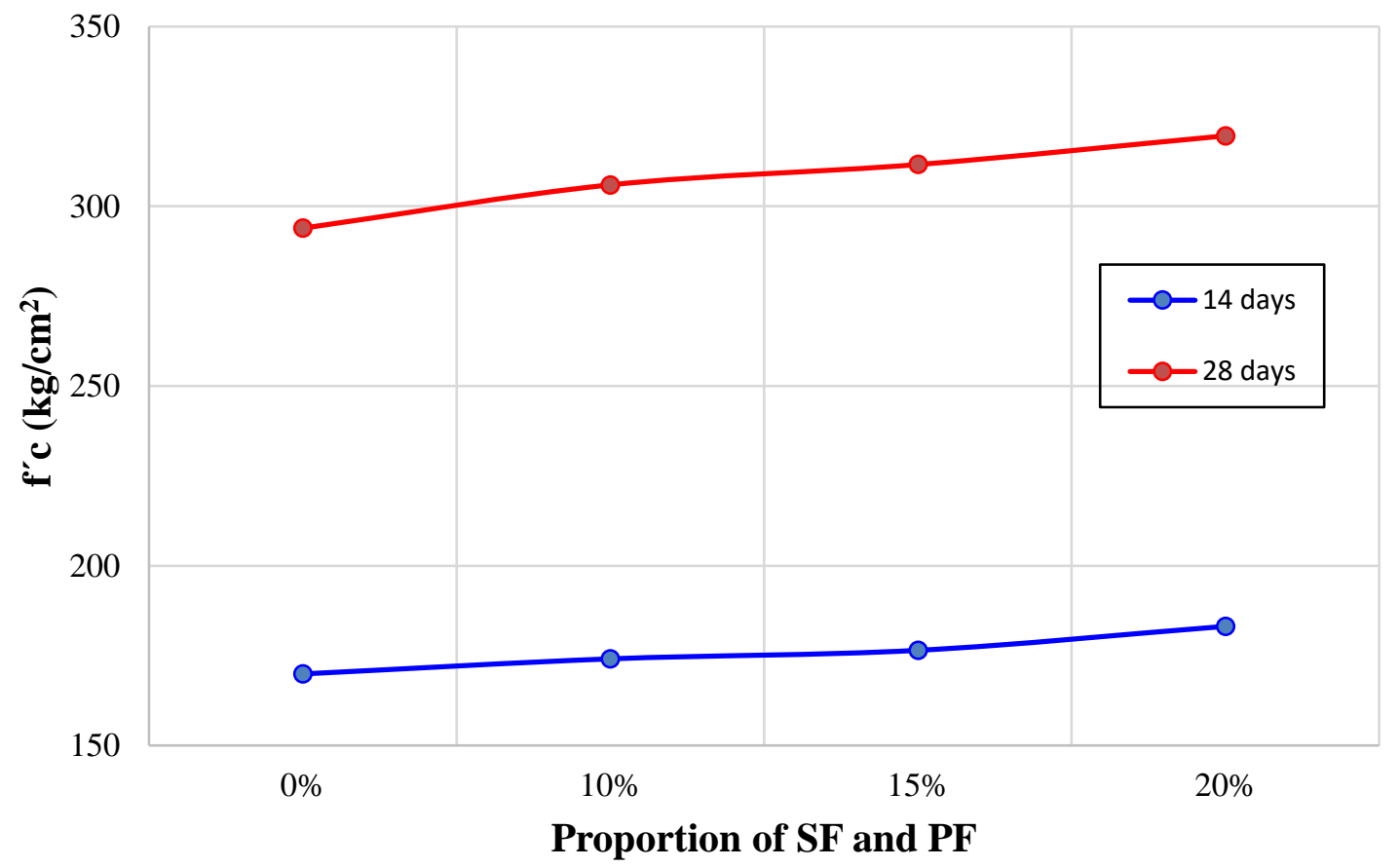

Figure 4. Resistance to compression according to SF and PF ratio.

\subsection{Statistical analysis of results}

Table 5. Analysis of variance (ANOVA of a factor) according to age of specimens

\begin{tabular}{|c|c|c|c|c|}
\hline $\begin{array}{c}\text { Age of } \\
\text { specimens }\end{array}$ & Mean & $\begin{array}{c}\text { Standard } \\
\text { deviation }\end{array}$ & F & Significance $(\mathrm{p})^{*}$ \\
\hline 14 days & 175.91 & 5.54 & 16.519 & 0.001 \\
\hline 28 days & 307.77 & 10.81 & 29.076 & 0.000 \\
\hline
\end{tabular}

* The difference in means is very significant at the 0.01 level $(\mathrm{p}<0.01)$

Table 6. Multiple comparison of concrete specimen samples by age.

\begin{tabular}{|c|c|c|c|c|}
\hline Samples & SC10SPF & SC15SPF & SC20SPF & SC \\
\hline \multicolumn{5}{|c|}{ 14 days } \\
\hline SC10SPF & ----------- & 0.630 & $0.007^{* *}$ & 0.208 \\
\hline SC15SPF & & --------- & $0.035^{*}$ & $0.038^{*}$ \\
\hline SC20SPF & & -------- & $0.001^{* *}$ \\
\hline SC & & -------- \\
\hline \multicolumn{5}{|c|}{28 days } \\
\hline SC10SPF & ----------- & 0.266 & $0.006^{* *}$ & $0.012^{*}$ \\
\hline SC15SPF & & --------- & 0.086 & $0.001^{* *}$ \\
\hline SC20SPF & & & --------- & $0.000^{* *}$ \\
\hline SC & & & & --------- \\
\hline
\end{tabular}


$*$ The difference in means is significant at the 0.05 level $(\mathrm{p}<0.05)$

** The difference in means is very significant at the 0.01 level $(\mathrm{p}<0.01)$

\section{DISCUSSION OF RESULTS}

\subsection{Fresh Concrete Slump}

In table 3 it can be seen that the largest slump occurred in the SC Control Group (3.7"), and with the incorporation of SF and PF in their three proportions it decreased by up to $19 \%$, evidencing a decrease in the workability and handling of the concrete when these fibers were added. This is confirmed by Patil and Shinde (2016) [16] when adding steel fiber and Alwesabi, Bakar, Alshaikh and Akil (2019) [17] using hybrid steel and polypropylene fibers. Likewise, Armas (2016) [18] had decreases between 23 and 53\% (from 3.8" to 2.91 and 1.77) when adding ultra-fine Chema PF. Sotil and Zegarra (2015) [19] also experienced decreases in slump of up to $25 \%$ with the addition of this material. On the other hand, De la Cruz and Quispe (2014) [20] determined that this property is influenced by the addition of steel filaments, with a predominant reduction in the slumping of the mixture of up to $8 \%$. Mashrei, Sultan and Mahdi (2018) [21] confirm that using PF in reduced percentages (less than 1\%) does not have negative effects on workability. It is clearly observed that the addition of steel and polypropylene fibers decreases slump, which can be solved by modifying the proportion of materials in the mixture or by adding a type of plasticizing additive to achieve a more workable mixture.

\subsection{Resistance to Compression}

Table 4 shows the values of resistance to compression for all mixtures at 14 and 28 days, as well as their trend and evolution in Figures 3 and 4. The resistance to compression increased when SF and PF fibers were used, and the SC20SPF mixture (with 20\% SF and 20\% PF) reached a higher value; its variation was +7.8 and $+8.7 \%$ regarding the $\mathrm{SC}$ for 14 and 28 days respectively. Alwesabi, Bakar, Alshaikh and Akil (2019) [17] it was also verified that the resistance to compression is increased by using an optimal combination of steel and polypropylene fibers of $0.1 \%$ and $0.9 \%$ of the cement weight respectively, reaching $25.8 \%$ higher than the control mixture. Similar results were also found by Yap, Bu, Alengaram, Mo and Jumaat (2014) [22] when using these two types of fibers. Liu, Wu, Yang and Wei (2019) [23] determined a better compression resistance performance when using SF and PF achieving a positive variation of up to $15 \%$ above the concrete control in the same test age. It can be noted that the addition of PF to the mixture improves the bond between the aggregate particles and the cement mortar, which decreases the air content and then increases the density of the concrete samples. It can be said that the SF and PF fibers have a positive synergistic effect [24], improving compression resistance and crack control.

For their part, Quintana and Valencia (2016) [25] showed that adding steel fibers at 14 days exceeds $30 \%$ of the expected design strength; at 21 days, $38 \%$ and at 28 days $44 \%$ was obtained above the expected resistance. Armas (2016) [18] mentions that the mechanical properties of concrete are increased with the addition of polypropylene fiber, approximately $3 \%$ and $14 \%$ at the age of 28 days, respectively. The dose of $400 \mathrm{gr} / \mathrm{m}^{3}$, Armas adds, generates a compressive strength after 28 days of $187.23,216.32$ and $307.93 \mathrm{~kg} / \mathrm{cm}^{2}$ for the standard designs of 175 , 210 and $280 \mathrm{~kg} / \mathrm{cm}^{2}$. In this regard, Gutiérrez and Palomino (2015) [26] affirm that, in a concrete of resistance $280 \mathrm{~kg} / \mathrm{cm}^{2}$ when adhering CHO 80/60 fibers for dosages of 20, 25 and $30 \mathrm{~kg} / \mathrm{m}^{3}$, increases the resistance to compression up to in $19 \%, 23 \%$ and $22 \%$. For PP65 fiber in dosages of 2, 5.5 and $9 \mathrm{~kg} / \mathrm{m}^{3}$, it increases up to $8 \%, 21 \%$ and $17 \%$. Likewise, Elizondo, Monge and Navas (2013) [27] and Fernández (2013) [28], state that steel and polypropylene 
fibers improve the mechanical properties of concrete, increasing its resistance to compression, durability, dynamic fatigue and traction. Mastali, Dalvand, Sattarifard, Abdollahnejad and Illikainen (2018) [29] state that the use of different types of fibers, either alone or in combination, ensure different orientations and distribution in the mixture, providing union between the fiber and the cement mortar, mechanical anchorage and ability to stop crack propagation [30]. They also highlight that the shape of the steel fiber end and a not very smooth surface must be fundamental characteristics to guarantee better performance of the mechanical properties.

\subsection{Statistical Analysis}

Regarding the behavior of mixtures with SF and PF fibers in the resistance to compression of concrete, in table 5 it is observed that there are very significant variations $(\mathrm{p}<0.01)$ between the resistances of each age group, which would be confirming that the addition of steel and polypropylene fibers positively alters the mechanical properties of concrete. Table 6 shows multiple comparisons between the mixtures, showing that at 14 and 28 days the samples with the addition of SF and PF tend to differ from the control mixture (SC). At 14 days the very significant difference is given between the SC20SPF and SC mixtures $(\mathrm{p}<0.01)$ and by 28 days, it is observed that the difference between these groups increases. Therefore, it is evident that the presence of steel and polypropylene fibers significantly influences the compressive strength of concrete.

\section{CONCLUSIONS}

In this article the effect of SF and PF on the compressive strength of concrete was investigated. Based on the experimental results, the following main conclusions can be drawn:

1. The results of tests carried out on fresh concrete show that mixtures with SF (steel fibers) and PF (polypropylene fibers) reduce workability by up to $19 \%$ with respect to SC.

2. The combination of SF and PF in the SC10SPF, SC15SPF and SC20SPF mixtures reduces the workability and handling of concrete due to the lack of cement mortar.

3. SF and PF fibers significantly influence the compressive strength of concrete. The maximum average strength was obtained by the SC20SPF mix with a $20 \%$ dosage of SF and PF, being the average strength for 14 days $183.15 \mathrm{~kg} / \mathrm{cm}^{2}$ and for 28 days $319.61 \mathrm{~kg} / \mathrm{cm}^{2}$.

4. The combination of $\mathrm{SF}$ and $\mathrm{PF}$ added to the mixtures increases the compressive strength by $8.7 \%$ for SC20SPF, 6\% for SC15SPF and 4\% for SC10SPF, all with respect to the $\mathrm{SC}$ mixture.

\section{REFERENCIAS}

[1] Rivera, G. Tecnología del concreto y mortero. Ciudad del Cauca: Universidad del Cauca, 2009, pp. 235.

[2] ACI 544. Report on Fiber Reinforced Concrete. American Concrete Institute (ACI), 1996

[3] Sika. Fiber CHO 65-35-NB, Edición 6. Lima, 2015.

[4] Sika. Concreto reforzado con fibras. Edición 1. Lima, 2011.

[5] Municipalidad Provincial de Trujillo. (14 de octubre de 2015). http://www.munitrujillo.gob.pe/noticiasmpt/categorias/areasverdes/el-60--de-

construcciones-en-trujillo-es-informal- 
[6] NTP 339.034 Concreto. Método de ensayo normalizado para la determinación de la resistencia a la compresión del concreto en muestras cilíndricas. 4a. Edición. Norma Técnica Peruana (NTP), 2015.

[7] ACI. Diseño de mezclas de concreto. American Concrete Institute (ACI), 2010.

[8] NTP 339.035 Concreto. Método de ensayo para la medición del asentamiento del concreto de Cemento Portland. 4a. Edición. Norma Técnica Peruana (NTP), 2015.

[9] ASTM C143 Standard Test Method for Slump of Hydraulic Cement Concrete. American Society for Testing and Materials (ASTM), 2015.

[10] ASTM C39 Standard Test Method for Compressive Strength of Cylindrical Concrete Specimens. American Society for Testing and Materials (ASTM), 2018.

[11] ASTM C129 Standard Specification for Nonloadbearing Concrete Masonry Units. American Society for Testing and Materials (ASTM), 2017.

[12] ASTM C29 Standard Test Method for Bulk Density ("Unit Weight") and Voids in Aggregate. American Society for Testing and Materials (ASTM), 2017.

[13] ASTM D2216 Standard Test Methods for Laboratory Determination of Water (Moisture) Content of Soil and Rock by Mass. American Society for Testing and Materials (ASTM), 2019.

[14] ASTM C125 Standard Terminology Relating to Concrete and Concrete Aggregates. American Society for Testing and Materials (ASTM), 2019.

[15] ASTM C33 Standard Specification for Concrete Aggregates. American Society for Testing and Materials (ASTM), 2018.

[16] Patil, A.D. and Shinde, D.N. Experimental Study on Characteristic Strengths of Steel Fiber Reinforced Concrete. International Research Journal of Engineering and Technology (IRJET), 3(6), 2016, 1765-1769. https://www.irjet.net/archives/V3/i6/IRJET-V3I6328.pdf

[17] Alwesabi, E.A.H., Bakar, B.H.A., Alshaikh, I.M.H. and Akil, H.M. Experimental investigation on mechanical properties of plain and rubberised concretes with steelpolypropylene hybrid fibre. Construction and Building Materials, 233(2020), 2019, 117194, doi: https://doi.org/10.1016/j.conbuildmat.2019.117194

[18] Armas, C. Efectos de la adición de fibra de polipropileno en las propiedades plásticas y mecánicas del concreto hidráulico. Rev. Ingeniería: Ciencia, Tecnología e Innovación, 3(2), 2016, 79-91. http://revistas.uss.edu.pe/index.php/ING/article/view/436/425

[19] Sotil, A. y Zegarra, J. Análisis comparativo del comportamiento del concreto sin refuerzo, concreto reforzado con fibras de acero WIRAND® FF3 y concreto reforzado con fibras de acero WIRAND® FF4 aplicado a losas industriales de pavimento rígido. Ingeniero Civil, Disertación, Lima-Perú: Universidad Peruana de Ciencias Aplicadas, 2015. https://repositorioacademico.upc.edu.pe/handle/10757/581616

[20] De La Cruz, W. y Quispe, W. Influencia de la adición de fibras de acero en el concreto empleado para pavimentos en la construcción de pistas en la provincia de HuamangaAyacucho. Ingeniero Civil, Disertación, Huamanga: Universidad Nacional de Huamanga, 2014. http://repositorio.unh.edu.pe/handle/UNH/239

[21] Mashrei, M.A., Sultan, A.A. and Mahdi, A.M. Effects of polypropylene fibers on compressive and flexural strength of concrete material. International Journal of Civil Engineering and Technology (IJCIET), 9(11), 2018, 2208-2217.

[22] Yap, S.P., Bu, C.H., Alengaram, U.J., Mo, K.H. and Jumaat, M.Z. Flexural toughness characteristics of steel-polypropylene hybrid fibre-reinforced oil palm shell concrete. Materials \& Design, 57, 2014, 652-659, doi: https://doi.org/10.1016/j.matdes.2014.01.004

[23] Liu, X., Wu, T., Yang, X. and Wei, H. Properties of self-compacting lightweight concrete reinforced with steel and polypropylene fibers. Construction and Building Materials, 226, 2019, 388-398, doi: https://doi.org/10.1016/j.conbuildmat.2019.07.306 
[24] Pakravan, H.R., Latifi, M. and Jamshidi, M. Hybrid short fiber reinforcement system in concrete: A review. Construction and Building Materials, 142, 2017, 280-294, doi: https://doi.org/10.1016/j.conbuildmat.2017.03.059

[25] Quintana, C. y Valencia, P. Análisis comparativo entre el concreto simple y el concreto con adición de fibra de acero al 12\% y 14\%. Ingeniero Civil, Disertación, Bogotá: Universidad Católica de Colombia, 2016.

[26] Gutiérrez, M. y Palomino, K. Análisis de las propiedades mecánicas del concreto reforzado con fibras de polipropileno y acero, y su uso en el control de fisuras por contracción plástica. Ingeniero Civil, Disertación, Arequipa: Universidad Católica de Santa María, 2015. http://tesis.ucsm.edu.pe/repositorio/handle/UCSM/2143

[27] Elizondo, A.L., Monge, S., Guillermo, L. y Navas, A. Evaluación del comportamiento de la fatiga de una mezcla de concreto MR-45 MPa con adición de polipropileno. Revista Ingeniería de Obras Civiles (RIOC), 3, 2013, 28-52. http://revistas.ufro.cl/ojs/index.php/rioc/article/view/1977

[28] Fernández, M. Hormigones reforzados con fibras de acero. Informes de la construcción, 34(342), 1982, 5-17.

[29] Mastali, M., Dalvand, A., Sattarifard, A.R., Abdollahnejad, Z. and Illikainen, M. Characterization and optimization of hardened properties of self consolidating concrete incorporating recycled steel, industrial steel, polypropylene and hybrid fibers. Composites Part B, 151, 2018, 186-200, doi: https://doi.org/10.1016/j.compositesb.2018.06.021

[30] De Alencar, V.M., Reis, L. and De Andrade, F. On the mechanical behavior of polypropylene, steel and hybrid fiber reinforced self-consolidating concrete. Construction and Building Materials, 188, 2018, 280-291, doi: https://doi.org/10.1016/j.conbuildmat.2018.08.103 